\title{
DISTRIBUSI KELIMPAHAN ICHTHYOPLANKTON DI TELUK TOMINI DAN LAUT BANDA
}

\author{
Muhammad Taufik', Suwarso"), dan Nurwiyanto")
}

\begin{abstract}
ABSTRAK
Penelitian ini bertujuan untuk mempelajari distribusi dan kelimpahan ichthyoplankton di Teluk Tomini dan Laut Banda, sebagai studi awal untuk mengkaji lokasi pemijahan ikan pelagis yang dominan di perairanperairan tersebut. Pada penelitian ini ditemukan 24 famili larva ikan di habitat pelagis Teluk Tomini dan 8 famili di habitat karang Kepulauan Togian. Di Laut Banda ditemukan 25 famili larva ikan. Kelimpahan larva terbesar di Teluk Tomini didominasi oleh famili Clupeidae, Carangidae, dan Scombridae, di Kepulauan Togian didominasi oleh famili Scombridae, Engraulidae, dan Carangidae; sedangkan di Laut Banda didominasi oleh famili Clupeidae, Scombridae, dan Ambassidae. Keterkaitan keberadaan populasi larva ikan dalam habitatnya juga dibahas.
\end{abstract}

\section{ABSTRACT: Preliminary study on the distribution and abundance of ichthyoplankton in Tomini} Bay and Banda Sea. By: Muhammad Taufik, Suwarso, and Nurwiyanto

Study on the distribution and abundance of Ichthyoplankton was carried out in Tomini Bay and Banda Sea as a preliminary study to identify the spawning sites of the dominant pelagic fishes in the waters. A number of 24 families of ichthyoplankton was identified in the pelagic habitat in Tomini Bay, 8 families of ichthyoplankton in Togean Islands, and 25 families of ichthyoplankton in Banda Sea. Higher abundance of larval fish in Tomini Bay was dominated by family Clupeidae, Carangidae, and Scombridae, in Togean Islands was dominated by family Scombridae, Engraulidae, and Carangidae; while in Banda Sea the fish larvals of Clupeidae. Scombridae, and Ambassidae were also abundant. Possible relationships of the existence of larval population in their habitats was also discussed

KEYWORDS: ichthyoplankton or larvae, distribution, abundance, Tomini Bay, Togian Islands, Banda Sea

\section{PENDAHULUAN}

Ichthyoplankton (larva ikan) merupakan bagian dari kelompok meroplankton pada tahap awal kehidupan dari ikan (Pisces) setelah telur menetas (early life history). Pada tahap berikutnya meroplankton berubah menjadi ikan pelagis berenang bebas sebagai nekton. Terdapat keterkaitan yang sangat erat antara fitoplankton, zooplankton, dan ichthyoplankton dalam suatu jaring-jaring makanan di laut (Romimohtarto et al., 1998). Studi tentang telur ikan (fish egg) dan larva ikan (fish larvae) di bidang perikanan sangat penting terutama untuk mengetahui lokasi dan waktu pemijahan dari suatu populasi ikan dengan ketepatan yang lebih tinggi (Van Nguyen, 2001) dibandingkan dengan cara konvensional lainnya (perkembangan maturity). Dalam skala yang lebih luas penelitian di bidang ini juga untuk menduga potensi reproduktif parents stocks serta recruitment yang sangat penting bagi pengelolaan perikanan. Hempel (1974) dalam Westhaus-Ekau (2004) menambahkan 4 tujuan utama dalam penelitian larva, yaitu 1) memberikan pengetahuan umum tentang morfogenesis, fisiologi, tingkah laku, taksonomi, sistematik, dan zoogeografi; 2) peran telur atau larva dalam ekosistem perairan dan jaring-jaring makanan; 3) untuk kepentingan uji toksikologi, fisiologi, dan studi genetik dan untuk kepetingan identifikasi spesies yang belum dikenal; dan 4) mempelajari populasi ikan dan eksploitasi optimumnya.

Penelitian tentang larva ikan di Indonesia sangat kurang. Bagi stok perikanan, sementara ini diduga terdapat sifat spawning migration ikan pelagis, karena pada kenyataannya sangat sulit untuk menduga lokasi pemijahannya (Suherman et al., 1995). Terkait dengan potensi sumber daya ikan pelagis (pelagis kecil dan pelagis besar) di Teluk Tomini dan Laut Banda studi ini dilaksanakan. Dalam tulisan ini disajikan hasil studi pendahuluan tentang distribusi dan kelimpahan larva ikan di perairan-perairan tersebut; hasilnya diharapkan dapat bermanfaat bagi pengembangan yang lebih komprehensif guna mendukung perumusan bahan kebijakan pengelolaan dan pemanfaatan perikanan.

\section{BAHAN DAN METODE}

\section{Pengambilan Contoh}

Pengambilan contoh larva atau telur dilakukan bersamaan dengan pengambilan contoh akustik dan oseanografi (fisik) pada stasiun-stasiun yang telah ditentukan, masing-masing 36 stasiun di habitat pelagis Teluk Tomini (epipelagic zone), 16 stasiun di

\footnotetext{
Peneliti pada Balai Riset Perikanan Laut, Jakarta

*) Teknisi Litkayasa pada Balai Riset Perikanan Laut, Jakarta
} 
habitat karang Kepulauan Togian dan 21 stasiun di habitat pelagis Laut Banda. Pengambilan contoh di Teluk Tomini dilaksanakan pada bulan Juli atau Agustus 2003 (musim timur), di Kepulauan Togean pada bulan Desember 2004 (musim barat), sedangkan di Laut Banda pada bulan Oktober 2003. Posisi stasiun dipresentasikan pada Gambar 1.

Pengambilan contoh dilakukan secara horisontal di lapisan permukaan pada kedalaman 1 sampai dengan
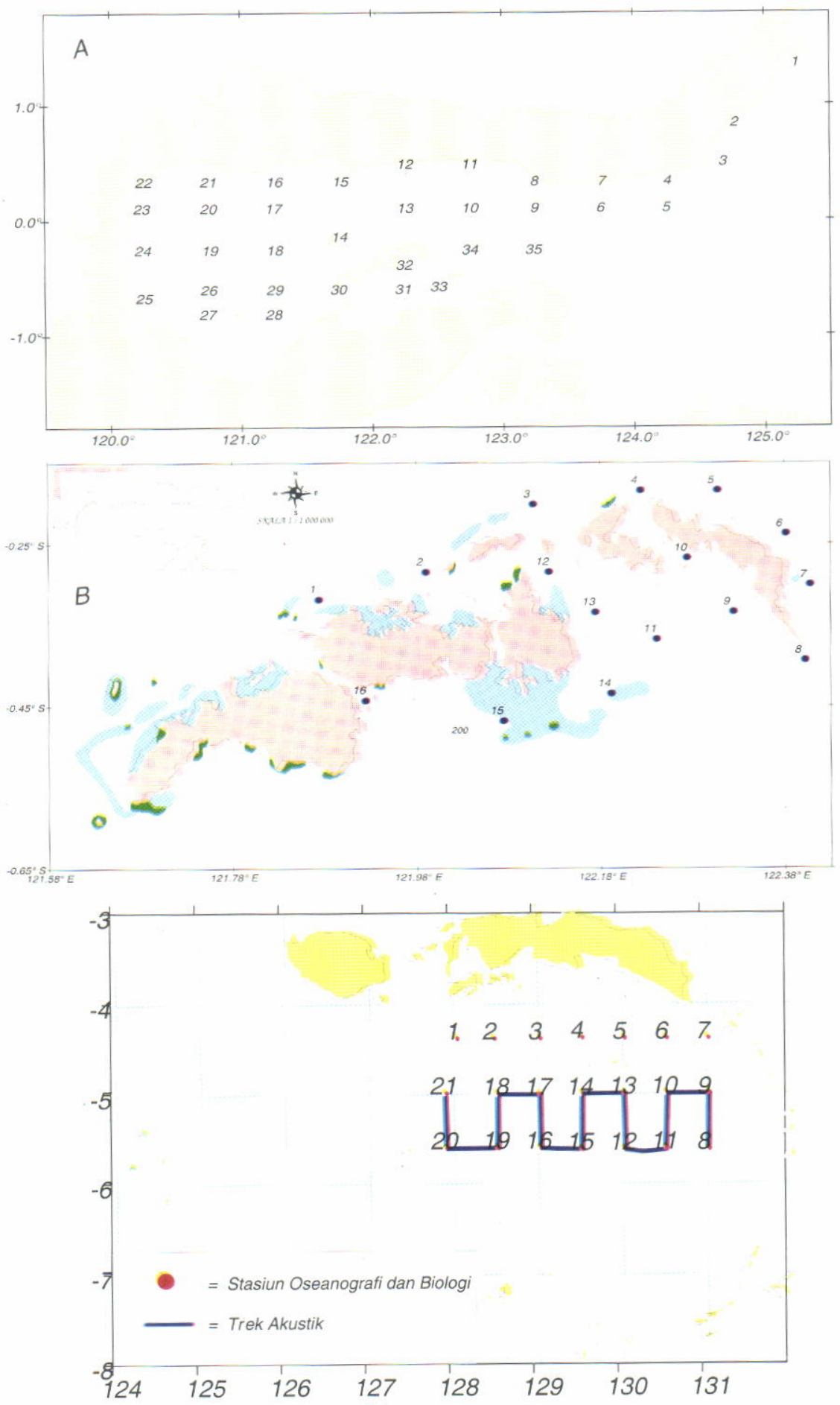

Gambar 1. Lokasi stasiun pengambilan contoh larva atau telur dan plankton di Teluk Tomini, bulan Juli atau Agustus 2003 (A), Kepulauan Togean, Desember 2004 (B) dan Laut Banda, Oktober 2003 (C).

Figure 1. Sampling station the larvae or eggs and plankton in Tomini Bay, July or August 2003 (A), Togean Islands, December 2004 (B) dan Banda Sea, October 2003 (C). 
$5 \mathrm{~m}$ dengan menggunakan bongo net berdiameter 62 $\mathrm{cm}$ mesh size $500 \mu$. Penarikan Bongo net dilakukan dengan kecepatan antara 1,4 sampai dengan 2,8 knot selama 15 sampai dengan 20 menit. Contoh larva yang tersaring diawetkan dengan Iarutan formalin $7,5 \%$, setelah disortir contoh larva disimpan dalam larutan alkohol $96 \%$.

\section{Analisis}

Pengamatan larva meliputi identifikasi dan jumlah individu; identifikasi dilakukan sampai dengan tingkat famili berdasarkan pada karakteristik umum dari setiap famili seperti diuraikan oleh Leis \& Trnski (1989), Leis \& Rennis (1989), Sa-nga Vatanachai (1972), Anonymous (1975), Westhaus-Ekau (2004), dan Soewito (1987). Sebelum identifikasi, dilakukan penyortiran untuk memisahkan kelompok ichthyoplankton dengan zooplankton dari contoh yang dikumpulkan. Penghitungan larva ikan dan zooplankton dilakukan secara terpisah. Pengamatan dilakukan dengan menggunakan mikroskop stereo dengan perbesaran 40x. Visualisasi kelimpahan dilaksanakan berdasarkan pada jumlah larva atau telur yang tersaring bongo net selama waktu penarikan dengan asumsi bahwa volume air tersaring sama.

\section{HASIL DAN BAHASAN}

\section{Sebaran Kelimpahan Ichthyoplankton di Teluk} Tomini pada Musim Timur

Dari pengambilan contoh pada bulan Juli atau Agustus 2003 di perairan Teluk Tomini ditemukan 24 famili larva ikan di mana 3 famili di antaranya paling dominan, yaitu Clupeidae, Scombridae, dan Carangidae, masing-masing memiliki kontribusi $38 \%$, $19 \%$, dan $14 \%$ (Tabel 1). Secara keseluruhan diperoleh 695 individu larva dalam volume air tersaring antara $125 \mathrm{~m}^{3}$ sampai dengan $651 \mathrm{~m}^{3}$; kelimpahan larva pada tiap stasiun berkisar antara 1 sampai dengan 88 individu (rata-rata 22 individu per stasiun) yang termasuk ke dalam 1 sampai dengan 13 famili. Selain ke-3 famili tersebut di Teluk Tomini juga ditemukan beberapa famili ikan karang seperti Holocentridae, Acanthuridae, dan Scaridae. Beberapa gambar larva ikan yang ditemukan di Teluk Tomini, Kepulauan Togian dan Laut Banda dapat dilihat pada Lampiran 1.

Dari keseluruhan 695 individu larva yang ditemukan kelimpahan tertinggi sekitar 41 sampai dengan 88 individu per stasiun ditemukan di perairan sebelah selatan Marisa sampai dengan Gorontalo, yaitu stasiun $8,12,13,15$, dan 16 , di sekitar mulut teluk sebelah utara (stasiun 3) juga memiliki kelimpahan cukup besar; kelimpahan yang rendah pada umumnya ditemukan di pantai utara Poso dan perairan sebelah selatan Kepulauan Togian (stasiun 27, 31, dan 32). Variasi secara spasial dari kelimpahan ichthyoplankton pada musim timur dipresentasikan pada Tabel 2 dan Gambar 2.

Stasiun dengan jumlah famili terbanyak (13 famili) adalah stasiun 16. Tiga famili paling dominan (Clupeidae, Scombridae, dan Carangidae) ditemukan memiliki penyebaran lebih luas di perairan oseanik, kecuali stasiun-stasiun di sepanjang pantai utara Sulawesi Tengah. Kelimpahan tertinggi dari famili Clupeidae 27 individu ditemukan di stasiun 15 (pantai selatan Marisa), sedangkan famili Scombridae (27 individu) dan Carangidae (16 individu) ditemukan di stasiun 8 (pantai selatan Gorontalo). Sebaran kelimpahan 3 famili ichthyoplankton yang dominan dipresentasikan pada Gambar 2.

Di perairan Teluk Tomini ikan dari famili Clupeidae, Scombridae, dan Carangidae merupakan kelompok ikan pelagis yang penting. Malalugis (Decapterus macarellus) dan katombo (Selar crumenophthalmus) adalah jenis ikan pelagis kecil yang utama dari famili Carangidae yang banyak tertangkap purse seine.

Tabel 1. Komposisi ichthyoplankton menurut famili di perairan Teluk Tomini pada bulan Juli atau Agustus 2003 (musim timur)

Table 1. IChthyoplankton composition according to family in the waters of Tomini Bay, July or August 2003 (east season)

\begin{tabular}{|c|c|c|c|}
\hline No. & $\begin{array}{l}\text { Famili/ } \\
\text { Family }\end{array}$ & $\begin{array}{c}\text { Kelimpahan/ } \\
\text { Abundance }\end{array}$ & $\%$ \\
\hline 1. & Clupeidae & 311 & 38 \\
\hline 2. & Scombridae & 153 & 19 \\
\hline 3. & Carangidae & 112 & 14 \\
\hline 4. & Tak teridentifikasi & 68 & 8 \\
\hline 5. & Ambassidae & 34 & 4 \\
\hline 6. & Echeneidae & 13 & 1 \\
\hline 7. & Engarulididae & 12 & 2 \\
\hline 8. & Caproidae & 11 & 1 \\
\hline \multirow[t]{2}{*}{9.} & Lainnya & 84 & 11 \\
\hline & Jumlah & 798 & 100 \\
\hline
\end{tabular}


Tabel 2. Kelimpahan (ind. $\mathrm{m}^{-3}$ ) dan jumlah famili ichthyoplankton yang ditemukan di setiap stasiun di Teluk Tomini pada bulan Juli atau Agustus 2003

Table 2. IChthyoplankton abundance (ind. $\mathrm{m}^{-3}$ ) and numbers of fish family found in each location in Tomini Bay, July or August 2003

\begin{tabular}{cccccc}
\hline Stasiun & $\begin{array}{c}\text { Kelimpahan/ } \\
\text { Abundance }\end{array}$ & $\begin{array}{c}\text { Famili/ } \\
\text { Family }\end{array}$ & Stasiun & $\begin{array}{c}\text { Kelimpahan/ } \\
\text { Abundance }\end{array}$ & $\begin{array}{c}\text { Famili } \\
\text { Family }\end{array}$ \\
\hline 1 & 24 & 10 & 19 & 13 & 5 \\
2 & 28 & 5 & 20 & 6 & 4 \\
3 & 52 & 9 & 21 & 26 & 5 \\
4 & 6 & 4 & 22 & 9 & 4 \\
5 & 7 & 2 & 23 & 8 & 5 \\
6 & 9 & 3 & 24 & 6 & 4 \\
7 & 21 & 4 & 25 & 9 & 4 \\
8 & 88 & 10 & 26 & 9 & 1 \\
9 & 10 & 4 & 27 & 1 & 4 \\
10 & 24 & 5 & 28 & 4 & 7 \\
11 & 10 & 3 & 29 & 22 & 5 \\
12 & 71 & 7 & 30 & 14 & 2 \\
13 & 41 & 7 & 31 & 4 & 4 \\
14 & 3 & 2 & 32 & 2 & 1 \\
15 & 49 & 6 & 33 & 31 & $*$ \\
16 & 51 & 13 & 34 & 1 & 3 \\
17 & 12 & 6 & 35 & 1 & \\
18 & 17 & 6 & 36 & 6 & \\
\hline Keterangan * ${ }^{*}$ tak diketahui & & & & & 4 \\
\hline
\end{tabular}

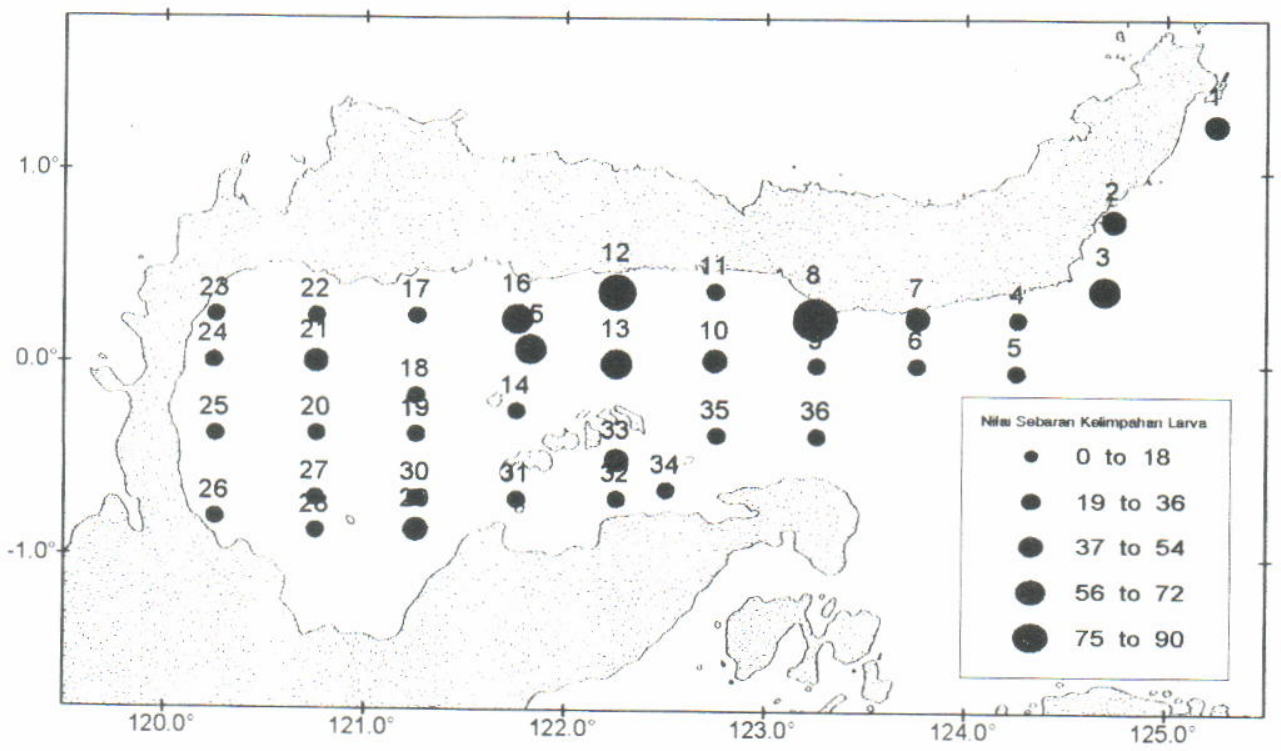

Gambar 2. Sebaran spatial ichthyoplankton di Teluk Tomini pada bulan Juli atau Agustus 2003 (musim

Figure 2. timur).

Ichthyoplankton spatial distribution in Tomini Bay, July or August 2003.

Madidihang atau yellowfin tuna atau tuna sirip kuning (Thunnus albacares) adalah salah satu jenis ikan dari famili Scombridae yang melimpah dan menjadi target penangkapan nelayan pancing tuna (handline). Tiga jenis Scombridae lainnya yang juga melimpah antara lain 2 spesies yang termasuk kelompok ikan pelagis besar, yaitu cakalang (Katsuwonus pelamis) dan tongkol (Euthynnus spp.), masing-masing merupakan target penangkapan alat huhate ( $\mathrm{pool}$ and line) dan jaring gill net; sedangkan solisi (Rastrelliger kanagurta) dominan dalam hasil tangkapan purse seine (Fayakun S. et al., 2005; Dalam terbitan ini; Hariati et al., 2005). Juwana ikan tuna (ukuran 25 sampai dengan $45 \mathrm{~cm}$ ), cakalang (15 sampai dengan 
$20 \mathrm{~cm}$ ) dan tongkol (ukuran 13 sampai dengan $17 \mathrm{~cm}$ ) juga ditemukan cukup banyak dalam hasil tangkapan purse seine.

Keberadaan larva ikan sangat dipengaruhi oleh beberapa faktor lingkungan fisik, tingkah laku induk dan ketersediaan makanan pada habitatnya (Romimohtarto et al., 1998). Selain sebagai perairan yang bersifat semi tertutup dan terlindung, dalam skala global perairan Teluk Tomini juga memiliki suhu permukaan yang lebih tinggi dibanding perairan di sekitarnya (Laut Maluku dan Teluk Tolo), serta memiliki potensi kesuburan (klorofil) sangat tinggi terutama di perairan sekitar mulut teluk (Amri et al., 2005; Dalam terbitan ini) yang merupakan prasyarat utama bagi kehidupan zooplankton dan ichthyoplankton. Penyebaran larva pada musim timur yang ditunjukkan oleh konsentrasi kelimpahan larva di perairan sebelah selatan Marisa sampai dengan Gorontalo dan sekitar mulut teluk sangat dimungkinkan ditentukan oleh pola arus permukaan, angin, dan pasang surut musim timur. Pada musim timur arus permukaan yang cukup kencang mengalir dari arah tenggara, di daerah mulut terjadi pemecahan arus ke arah barat, barat laut, dan timur laut (Burhanuddin et al., 2004). Diperlukan kajian yang lebih detil untuk mengetahui keterkaitan antara penyebaran larva dan faktor-faktor lingkungan fisik yang menentukan.

Hasil kajian plankton oleh Awwaluddin et al. (2005; Dalam terbitan ini) menunjukkan total kelimpahan fitoplankton yang besar sekitar 80.010 sampai dengan 1.082 .520 sel $\mathrm{m}^{-3}$ (rata-rata 263.963 sel $\mathrm{m}^{-3}$ ), kelimpahan tertinggi tersebar di perairan sekitar mulut teluk; demikian juga halnya dengan konsentrasi penyebaran zooplankton. Tingginya jumlah larva ikan yang ditemukan di stasiun 8 dikarenakan terdapatnya sumber makanan bagi larva ikan yaitu zooplankton; Copepoda merupakan zooplankton yang dominan di stasiun ini. Selain makanan, kompetisi ruang, dan predasi diduga mempengaruhi keberadaan larva ikan. Di stasiun 27, 32, dan 35 larva yang ditemukan jumlahnya sedikit; hal ini diduga terjadi akibat tingginya jumlah zooplankton pemangsa larva ikan, yaitu Sagitta sp. Zooplankton Sagitta sp. merupakan salah satu zooplankton yang bersifat karnivora dan rakus yang suka memakan telur dan larva ikan (Sulistiono et al., 2001).

Hasil studi reproduksi terhadap ikan malalugis (Carangidae) menunjukkan bahwa waktu pemijahan jenis ini diduga dimulai sejak bulan Juli sampai dengan September (Suwarso et al., 2005; Dalam terbitan ini) dan waktunya bertepatan dengan puncak kesuburan (kondisi match mismatch) yang diduga terjadi sebagai akibat dari proses upwelling di daerah sekitar mulut teluk sebelah selatan atau sekitar Banggai pada musim timur (Wiadnyana, 1998) serta ditegaskan oleh karakteristik fisik massa air permukaan (Suwarso et al., 2005; Dalam terbitan ini). Ekosistim terumbu karang di Kepulauan Togian diduga juga berperan penting sebagai nursery ground dalam proses pemijahan ini.

\section{Sebaran Kelimpahan Ichthyoplankton di Kepulauan Togian (Teluk Tomini) pada Musim Barat}

Secara umum, kelimpahan larva ikan di sekitar Kepulauan Togean pada bulan Desember 2004 relatif rendah; ditemukan 9 kelompok famili larva ikan di mana 1 famili di antaranya tidak teridentifikasi. Ke-8 famili tersebut adalah Carangidae, Clupeidae, Engraulidae, Lutjanidae, Scombridae, Serranidae, Mugilidae, dan Sphyraenidae. Sebaran Kelimpahan ichtyoplaknton pada musim barat pada Gambar 3 .

Dalam volume air tersaring yang berkisar antara $169,01 \mathrm{~m}^{3}$ sampai dengan $325,94 \mathrm{~m}^{3}$ (rata-rata $239,55 \mathrm{~m}^{3}$ ) ditemukan kelimpahan larva relatif rendah, yaitu berkisar antara 0,3 sampai dengan 9,2 ind. per $100 \mathrm{~m}^{3}$; kelimpahan rata-rata larva ikan dari seluruh stasiun pengamatan di Kepulauan Togian adalah 0,371 ind per $100 \mathrm{~m}^{3}$ (Tabel 4). Kelimpahan yang lebih tinggi (6 sampai dengan 9 ind. $100 \mathrm{~m}^{-3}$ ) ditemukan di perairan sebelah selatan Pulau Waleakodi, Pulau Waleabahi (stasiun 10, 11, 12, 13, dan 14), suatu daerah yang terlindung, sedangkan di stasiun lainnya antara 0,3 sampai dengan 1,9 ind. 100

Tabel 3. Komposisi ichthyoplankton di Kepulauan Togian pada bulan Desember 2004 (musim barat) menurut kelompok famili

Table 3. Composition of ichthyoplankton (group family) around Togian Islands in December 2004

\begin{tabular}{|c|c|c|c|}
\hline No. & Famili & Jumlah & $\%$ \\
\hline 1. & Carangidae & 8 & 6 \\
\hline 2. & Clupeidae & 1 & 1 \\
\hline 3. & Engraulididae & 11 & 8 \\
\hline 4. & Scombridae & 73 & 52 \\
\hline 5. & Lutjanidae & 1 & 1 \\
\hline 6. & Serranidae & 1 & 1 \\
\hline 7. & Mugilidae & 2 & 1 \\
\hline 8. & Sphyraenidae & 1 & 1 \\
\hline \multirow[t]{2}{*}{9.} & Lainnya & 42 & 30 \\
\hline & Jumlah & 140 & 100 \\
\hline
\end{tabular}


$m^{-3}$. Rendahnya nilai kelimpahan larva di perairan ini mungkin dikarenakan memang perairan tersebut bukan merupakan nursery ground bagi larva ikan di samping indikasi bahwa musim barat bukan merupakan musim pemijahan. Pola arus permukaan menunjukkan mengalir dari arah tenggara dan utara (Suwarso et al., 2005; Dalam terbitan ini).
Pada Tabel 3 terlihat bahwa kelompok famili Scombridae merupakan famili yang paling banyak jumlahnya diikuti oleh kelompok lainnya (kelompok famili yang tidak teridentifikasi karena rusak selama penyimpanan), Engraulididae dan Carangidae. Larva Scombridae tersebar lebih merata, kelimpahan paling tinggi terdapat di stasiun 10. famili Scombridae

Tabel 4. Kelimpahan ichthyoplankton (per $100 \mathrm{~m}^{3}$ ) dan jumlah famili pada setiap stasiun di Kepulauan Togian pada bulan Desember 2004 (musim barat)

Table 4. Ichthyoplankton abundance (per $100 \mathrm{~m}^{3}$ ) and numbers of family group in each location of Togian Islands at December 2004 (west season)

\begin{tabular}{ccc}
\hline Stasiun & $\begin{array}{c}\text { Kelimpahan/ } \\
\text { Abundance }\end{array}$ & $\begin{array}{c}\text { Famili/ } \\
\text { Family }\end{array}$ \\
\hline 1 & 0,5 & 2 \\
2 & 0,3 & 1 \\
3 & 0,6 & 2 \\
4 & 1,1 & 2 \\
5 & 0,9 & 2 \\
6 & 0,4 & 1 \\
7 & 5,6 & 2 \\
8 & 0,7 & 1 \\
9 & 0,8 & 1 \\
10 & 9,2 & 3 \\
11 & 6,8 & 4 \\
12 & 9,2 & 8 \\
13 & 6,1 & 3 \\
14 & 5,9 & 3 \\
15 & 1,9 & 2 \\
16 & 0,4 & 1 \\
\hline
\end{tabular}

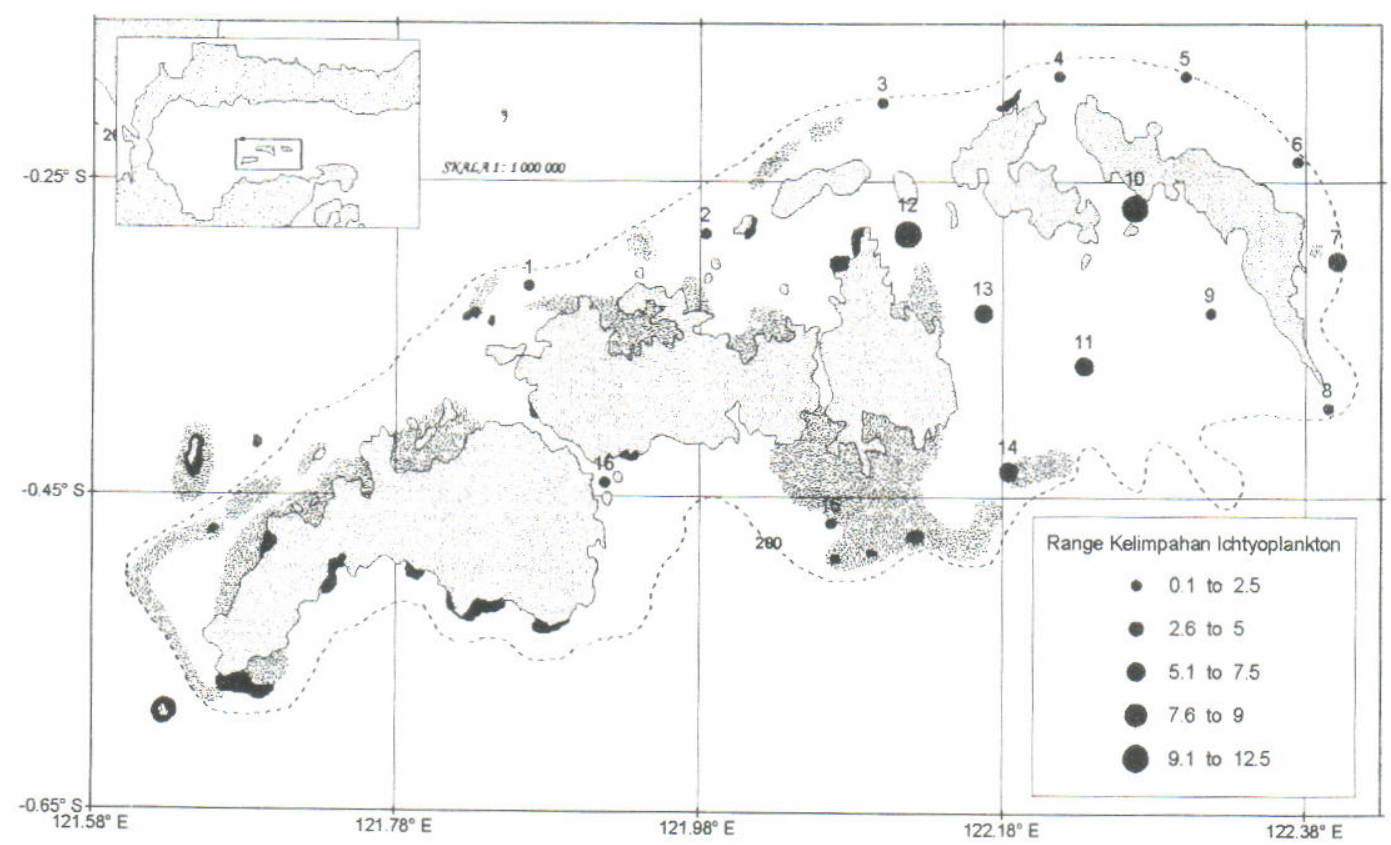

Gambar 3. Sebaran kelimpahan jumlah ichthyoplankton di perairan Kepulauan Togian pada bulan Desember 2004 (musim barat).

Figure 3. Distribution of ichthyoplankton abundance around Togian Islands in December 2004 (west season). 
merupakan kelompok famili di mana anggotanya antara lain terdiri atas tuna, cakalang, tongkol, tenggiri, dan solisi atau kembung, jenis-jenis ekonomis yang dominan di perairan ini. Selain di zona utama (perairan sebelah selatan Pulau Waleakodi dan Pulau Waleabahi), famili Engraulidae juga ditemukan di stasiun 1 dan 3 (sebelah utara dan barat laut) sedangkan famili Carangidae juga ditemukan $d$ stasiun 5 (sebelah timur laut). Perlu penelitian lebih lanjut kepentingan perairan karang Kepulauan Togian bagi kehidupan ichthyoplankton dari jenis ikan dominan. Sementara ini, diketahui terdapat indikasi terjadinya interaksi antara yellowfin tuna (Thunnus albacares) dengan daerah karang, yaitu ditemukannya ikan-ikan karang dalam isi lambungnya.

Sebaran Kelimpahan Ichthyoplankton di Laut Banda pada Bulan Oktober

Dari 21 stasiun contoh yang terambil di Laut Banda pada bulan Oktober 2003 ditemukan 484 individu larva yang termasuk ke dalam 25 kelompok ichthyoplankton (famili). Famili Clupeidae memiliki jumlah paling besar, yaitu sekitar 35\% dari keseluruhan larva yang terjaring, diikuti oleh famili Scombridae (26\%) (Tabel 5). Kelompok dominan lainnya adalah famili Carangidae, Ambassidae, dan Muraenescidae. Kelimpahan tertinggi terdapat di stasiun 5 dan 16 masing-masing 74 dan 87 individu; stasiun 2, 6, 9, 10, 11, dan 12 memiliki kelimpahan sedang (20 sampai dengan 43 individu), sedangkan di lokasi lainnya kelimpahan berkisar antara 2 sampai dengan 19 individu; di stasiun 1 tidak ditemukan larva ikan (Tabel 6). Rata-rata kelimpahan larva sekitar 44 ind. $\mathrm{M}^{-3}$, famili Clupeidae dan Scombridae tersebar lebih luas dan dapat ditemukan di 17 stasiun.

Laut Banda merupakan perairan yang memiliki potensi perikanan cukup besar, famili Scombridae dan Carangidae adalah kelompok yang penting. Dari kelompok ikan pelagis besar jenis-jenis ikan tuna ( $T$. albacares, $T$. obesus; Scombridae) adalah komoditi yang penting dan dominan dalam hasil tangkapan longline; sedangkan dari kelompok ikan pelagis kecil tercatat beberapa jenis yang penting, antara lain ikan momar (D. macarellus, Carangidae), kembung ( $R$. kanagurta, Scombridae), dan selar (S. crumenophthalmus, Selaroides leptolepis, dan selar lainnya, Carangidae), adalah jenis-jenis dominan dalam hasil tangkapan purse seine. Kepadatan populasi ikan yang tinggi di perairan tersebut terkait erat dengan tingkat kesuburan perairan yang tinggi, terutama pada musim timur, akibat proses upwelling musim. Menurut Arinardi et al (1997) hal ini ditunjukkan oleh kepadatan plankton yang tinggi; pada bulan Oktober atau Nopember kepadatan

Tabel 5. Komposisi larva di Laut Banda pada bulan Oktober 2003

Table 5. Ichthyoplankton composition in Banda Sea on October 2003

\begin{tabular}{cllcc}
\hline No. & & Famili & Jumlah & $\%$ \\
\hline 1. & Clupeidae & & 167 & 35 \\
2. & Scrombidae & & 124 & 26 \\
3. & Lainnya & 58 & 12 & 11 \\
4. & Ambassidae & & 51 & 9 \\
5. & Carangidae & & 42 & 6 \\
6. & Muraenescidae & & 29 & 100 \\
\hline
\end{tabular}

Tabel 6. Kelimpahan larva ikan dan jumlah famili yang ditemukan pada setiap stasiun di Laut Banda pada bulan Oktober 2003

Table 6. Ichthyoplankton abundance and numbers of fish family found in each sampling location on October 2003

\begin{tabular}{cccccc}
\hline Stasiun & $\begin{array}{c}\text { Kelimpahan/ } \\
\text { Abundance }\end{array}$ & $\begin{array}{c}\text { Famili/ } \\
\text { Family }\end{array}$ & Stasiun & $\begin{array}{c}\text { Kelimpahan/ } \\
\text { Abundance }\end{array}$ & $\begin{array}{c}\text { Famili/ } \\
\text { Family }\end{array}$ \\
\hline 1 & - & - & 12 & 43 & 5 \\
2 & 20 & 6 & 13 & 11 & 7 \\
3 & 7 & 4 & 14 & 3 & 2 \\
4 & 13 & 4 & 15 & 19 & 8 \\
5 & 74 & 9 & 16 & 87 & 13 \\
6 & 23 & 5 & 17 & 10 & 4 \\
7 & 13 & 4 & 18 & 3 & 3 \\
8 & 8 & 5 & 19 & 10 & 4 \\
9 & 38 & 7 & 20 & 9 & 3 \\
10 & 25 & 11 & 21 & & \\
\hline
\end{tabular}


plankton mencapai 41.429 sampai dengan 1.179.566 se $\mathrm{m}^{-3}$, sedangkan menurut Wiadnyana (1999), menyatakan bahwa pada musim upwelling (bulan Juli sampai dengan Agustus) kesuburan perairan dapat mencapai 15 kali lebih tinggi. Kelimpahan ichthyoplankton yang tinggi di perairan ini (pada bulan Oktober) diperkirakan juga bertepatan dengan puncak kesuburan dan kepadatan plankton di perairan ini. Faktor-faktor fisik perairan yang menciptakan kondisi stability bagi larva tidak diketahui

Fluktuasi kelimpahan menurut musim di ke-3 perairan belum diketahui, demikian juga keterkaitannya dengan faktor-faktor fisik dan biologi perairan. Studi larva yang lebih baik dalam skala ruang dan waktu yang lebih luas sangat bermanfaat bagi biologi perikanan (pemijahan, recruitment) untuk tujuan pengelolaan. Di samping itu perbaikan sistem pengambilan contoh juga sangat penting untuk hasil yang lebih akurat.

\section{KESIMPULAN}

Ditemukan 24 famili ichthyoplankton di Teluk Tomini, 8 famili di Kepulauan Togian dan 25 famili di Laut Banda; 3 famili di antaranya dominan di setiap perairan, yaitu Clupeidae, Scombridae, dan Carangidae dengan dominasi bervariasi menurut musim dan lokasi; ke-3 famili larva tersebut diduga mewakili jenis-jenis ikan dominan di setiap perairan. Kelimpahan larva pada sekitar musim timur cenderung lebih tinggi dengan famili Clupeidae paling dominan (Teluk Tomini dan Laut Banda), dibandingkan dengan musim barat yang lebih didominasi famili Scombridae.

\section{UCAPAN TERIMA KASIH}

Terima kasih kami sampaikan kepada tim survei Laut Banda (ketua tim: Drs. Karsono Wagiyo) yang telah membantu dalam pengumpulan contoh larva. Ucapan yang sama juga kami sampaikan kepada Dewi Eka Prasetyati, mahasiswi Program Studi IImu Kelautan Institut Pertanian Bogor yang telah membantu dalam analisis contoh yang dikumpulkan dari Teluk Tomini dan Laut Banda.

\section{DAFTAR PUSTAKA}

Anonimous. 1975. Ichthyoplankton. Technical paper in marine science No.20. Unesco. Mexito City.

Fayakun, S., Erfind N., \& Suwarso. 2005. Profil perikanan Teluk Tomini. Jurnal Penelitian Perikanan Indonesia Vol.11 No.6 Tahun 2005. Dalam terbitan ini. Jakarta.

Do Van Nguyen. 2001. Composition, abundance, and distribution of fish eggs and larvae. Proccedings of The $4^{\text {th }}$ Technical Seminar on Marine Fishery Resources Survey in The South China Sea, Area
IV: Vietnamese Waters. The Secretariat South East Fisheries Development Center. Bangkok.

Leis, J. M. \& T. Trnski. 1989. The larvae of Indo Pacific shorefishes. New South Wales University Press. New South Wales. Australia

Romimohtarto, Kasijan, \& Sri J. 1998. Plankton larva hewan laut. Pusat Penelitian Oseanografi. Lembaga IImu Pengetahuan Indonesia. Jakarta

Burhanuddin, S., Agus S., Budi S., Tukul R., \& Charles R. Kepel (eds.). 2004. Profil sumber daya kelautan dan perikanan Teluk Tomını. Badan Rıset Kelautan dan Perikanan. Departemen Kelautan dan Perikanan.

Sa-Nga, V. 1972. The identification of fish eggs and fish larvae obtained from the survey cruise in the South China Sea. Third Symposium on Marine Fisheries Laboratory. SEAFDEC

Soewito. 1987. Fish larvae of the Banda Sea (Indonesia I: Scombridae. Fellowship Progress Report No.3. Development Centre for Fishing Technology (BBPI). Directorat General of Fisheries. Semarang. Indonesia.

Suherman, B. A., B. Sadhotomo, \& Suwarso. 1995 Reproduction of the main small pelagic species in Potier, M. \& S. Nurhakim (eds.) BIODYNEX: Biology, dynamics, and exploitation of the small pelagic fishes in the Java Sea. AARD/ORSTOM.

Sulistiono, Rahardjo M. F., \& M. I. Effendi. 2001 Pengantar iktioplankton. Fakultas Perikanan dan IImu Kelautan. Institut Pertanian Bogor. Bogor.

Suwarso, Tuti H., \& A. Zamrony. 2005. Dugaan pemijahan dan biologi populasi ikan malalugis, Mackerel scad (Decaterus macarellus, CARANGIDAE) di Teluk Tomini.

Awwaluddin, Suwarso, \& Rahmat. 2005. Distribusi kelimpahan dan struktur komunitas plankton pada musim timur di perairan Teluk Tomini. Jurnal Penelitian Perikanan Indonesia Vol.11 No.6 Tahun 2005. Dalam terbitan ini. Jakarta.

Arinardi, O. H., A. B. Sutomo, S. A. Yusuf, Trimaningsih, E. Asnaryanti, \& E. Riyono. 1997. Kisaran kelimpahan dan komposisi plankton predominan di perairan kawasan timur Indonesia. Pusat Penelitian dan Pengembangan Oseanologi. Lembaga IImu Pengetahuan Indonesia. Jakarta.

Hariati, T. 2005. Perkembangan pemanfaatan ikan pelagis kecil menggunakan pukat cincin Sibolga di perairan barat Sumatera pada tahun 2003. Jurnal Penelitian Perikanan Indonesia Vol.11 No.2. Badan Riset Kelautan dan Perikanan. Departemen Kelautan dan Perikanan. Jakarta. 
Khairul, A., Suwarso, \& Herlisman. 2005. Dugaan potensi upwelling berdasarkan data citra satelit di perairan Teluk Tomini pada musim timur. Jurnal Penelitian Perikanan Indonesia Vol.11 No.6 Tahun 2005. Dalam terbitan ini. Jakarta.

Westhaus-Ekau, P. 2004. Early life history of fish: Marine fish eggs and larvae, development, ecology, and relation to fisheries. Marine Science Special Training Course MST-2004. Bogor Agricultural University Facutty of Fisheries and Marine Science-DAAD. Bogor.

Wyrtki, K. 1961. Physical oceanography of the Southeast Asian Waters. Naga Report, Vol. 2. The Univesrity of California. California. 195 p.

Wiadnyana, N. N. 1998. Distribusi dan variasi pigmen fitoplankton di Teluk Tomini, Sulawesi Utara. Prosiding Seminar Kelautan Lembaga IImu Kelautan dan Perikanan, Universitas Hasanuddin ke-1: Memacu llmu Pengetahuan dan Teknologi Kelautan untuk Menyongsong Era Globalisasi. Balai Penelitian dan Pengembangan Sumber Daya Laut. Pusat Penelitian dan Pengembangan Oseanologi. Lembaga IImu Pengetahuan Indonesia. Ambon.

Wiadnyana, N. N. 1999. Variasi kelimpahan zooplankton dalam kaitannya dengan produktivitas perairan Laut Banda. Oseanologi dan Limnologi di Indonesia. Pusat Penelitian dan Pengembangan Limnologi dan Pusat Penelitian dan Pengembangan Oseanologi. Lembaga llmu Pengetahuan Indonesia. Bogor dan Jakarta. 
Lampiran 1. Beberapa foto larva dan telur ikan yang ditemukan di Teluk Tomini, Kepulauan Togian dan Laut Banda

Appendix 1. Some several photos of egg fish and larvae caught in Tomini Bay, Togian Islands, and Banda Sea
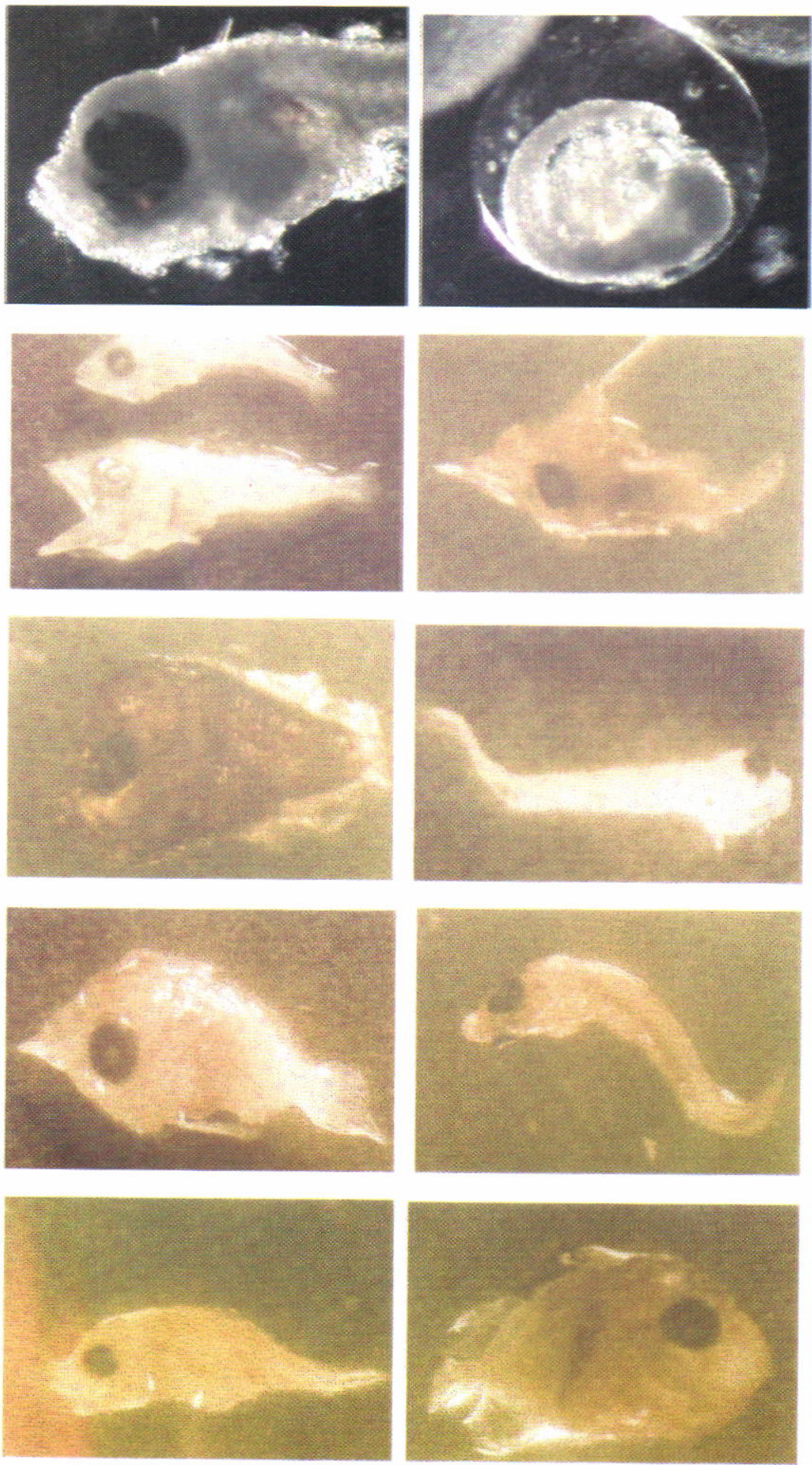

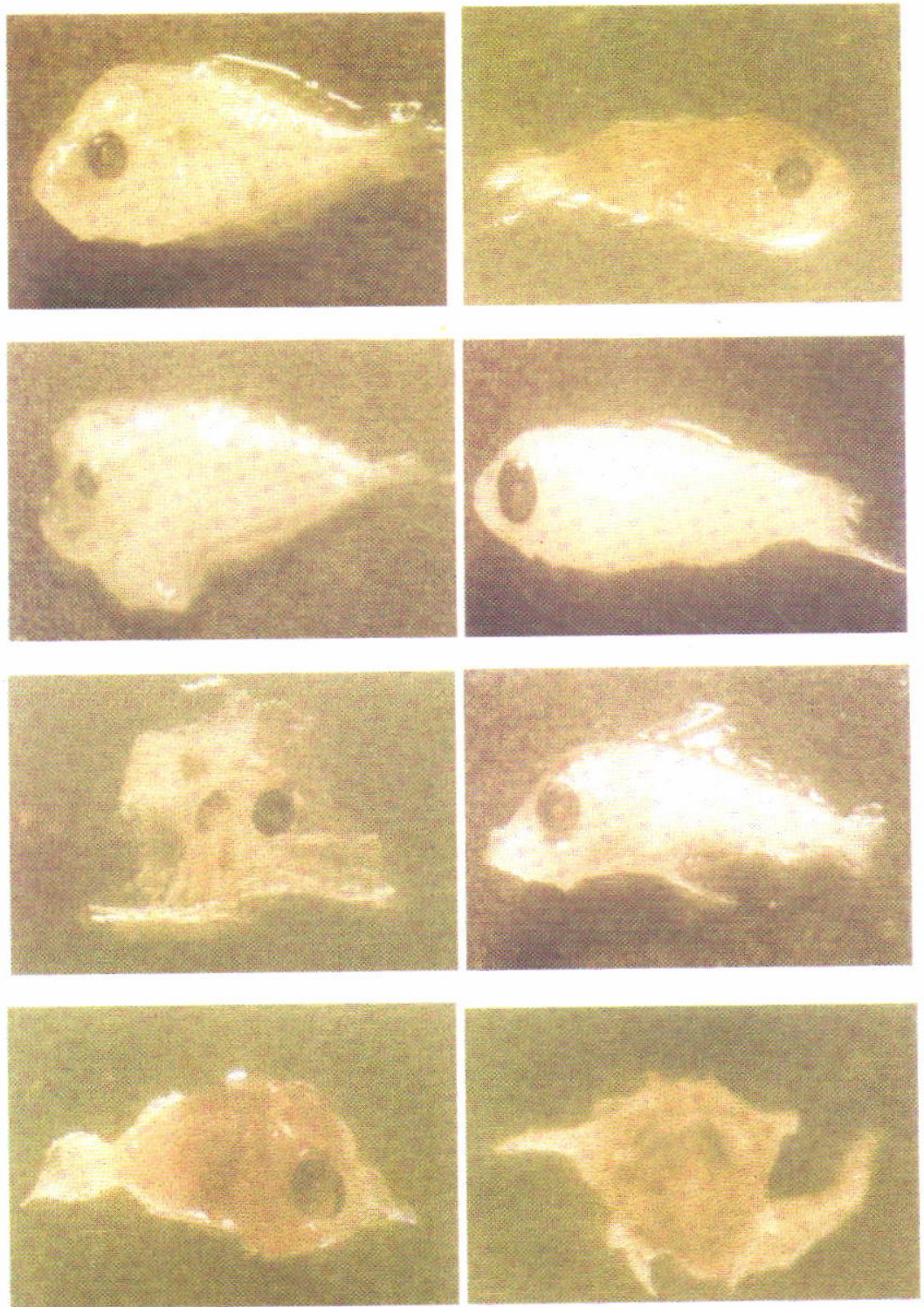

Keterangan/Remark:

$\begin{array}{ll}\text { 1. } & \text { Famili Clupeiade (Clupeinae) } \\ \text { 2. } & \text { Telur Ikan } \\ \text { 3. } & \text { Famili Scombridae } \\ \text { 4. } & \text { Famili Holocentridae } \\ \text { 5. } & \text { Famili Ephippidae } \\ \text { 6. } & \text { Famili Engraulididae } \\ \text { 7. } & \text { Famili Echeneididae } \\ \text { 8. } & \text { Famili Clupeidae (Dussumerinii) } \\ \text { 9. } & \text { Famili Cheilodactylidae }\end{array}$

10. Famili Creedidae

11. Famili Carangidae

12. Famili Caproidae

13. Famili Bothidae

14. Famili Ambassidae

15. Famili Acanthuridae

16. Famili Trichiuridae

17. Famili Symphysanodontidae

18. Famili Sparidae 
